\title{
EFFECT OF SUN EXPOSURE DURATION ON CYCLOOXYGENASE-2 EXPRESSION IN THE CONJUNCTIVA
}

\author{
Patricia Reisz Majić ${ }^{1}$, Branimir Cerovski², Petar Majić ${ }^{3}$, Ivan Krković $^{1}$, \\ Josip Barać ${ }^{1}$ and Ivanka Bradvica Štenc ${ }^{4}$
}

${ }^{1}$ Department of Ophthalmology and Optometry, Faculty of Medicine, Osijek University Hospital Centre, Josip Juraj Strossmayer University of Osijek, Osijek, Croatia;

${ }^{2}$ Department of Ophthalmology and Optometry, School of Medicine,

Zagreb University Hospital Centre, Zagreb, Croatia;

${ }^{3}$ Department of Radiology, Vukovar General Hospital, Vukovar, Croatia;

${ }^{4}$ Department of Neurology, Faculty of Medicine, Osijek University Hospital Centre,

Josip Juraj Strossmayer University of Osijek, Osijek, Croatia

\begin{abstract}
SUMMARY - Pterygium is a multifactorial proliferative pathologic change of bulbar conjunctiva. The purpose of this study was to determine the effect of the duration of exposure to solar radiation (expressed in years) on the incidence of positive cyclooxygenase-2 (COX-2) finding in conjunctival tissue in two groups of patients. Group 1 consisted of 68 patients with primary pterygium having undergone conjunctival autograft transplantation. Group 2 consisted of 43 patients with morphologically unchanged conjunctivae that were harvested during cataract surgery. All 111 specimens were submitted to immunohistochemical staining for monoclonal COX-2 antibody (1:100; M361701 MO A-HU, Dako, Santa Clara, California, USA). The immunostaining intensity in the surface epithelium was scored using the following grading system: 0 no immunostaining; + weak immunostaining (few cells being positive focally or scattered); ++ medium immunostaining; and +++ strong immunostaining (diffuse staining throughout the tissue). The analysis of COX-2 activity yielded 29 (42.6\%) positive findings in group 1 and $27(62.8 \%)$ positive findings in group 2. Group 2 consisted of statistically significantly older individuals with a history of considerably longer sun exposure. Statistical analysis proved the duration of exposure to solar radiation to be the most important factor in positive COX-2 findings.
\end{abstract}

Key words: Conjunctiva; Cyclooxygenase 2; Pterygium; Sunlight-adverse effects

\section{Introduction}

Pterygium is a common degenerative, triangular, fibrovascular, pathologic change of bulbar conjunctiva, which tends to ingrow subepithelially, from the limbus toward the centre of the cornea. Clinically, pterygium

Correspondence to: Patricia Reisz Majić, Department of Ophthalmology and Optometry, Faculty of Medicine, Osijek University Hospital Centre, Josip Juraj Strossmayer University of Osijek, Josipa Huttlera 4, HR-31000 Osijek, Croatia

E-mail: patriciareiszm@gmail.com

Received December 21, 2016, accepted September 6, 2017 can be divided into four grades by severity of changes (grade I, tissue affects the limbus; grade II, tissue on the limbus; grade III, tissue between the limbus and pupil; and grade IV, tissue extends beyond the pupil). It is assumed that different causal factors (inflammation, infection, ultraviolet (UV) exposure, chemical and mechanical irritants, human papilloma viruses) ${ }^{1}$ contribute to the development of pterygium. UV radiation $^{2-5}$ can induce cellular changes in the medial parts of the limbus ${ }^{6}$. Distribution of the incidence is related to particular geographical areas ${ }^{7-10}$. Older age 
and population living in rural areas are parameters related to long-term work in open areas and cumulated sun exposure, exposure to chemical and mechanical irritants, and chronic dryness of the eye surface. The present results suggest a multifactorial pathogenesis of pterygium and this study was focused on the inflammatory component ${ }^{11,12}$. Several cytokines such as transforming growth factor- $\beta$ (TGF- $\beta$ ), tumor necrosis factor $\alpha(\mathrm{TNF}-\alpha)$ and fibroblast growth factor (FGF) have been localized in both inflammatory and resident cells of pterygia. Kria et al. ${ }^{13}$ report that pterygium fibroblasts express fibroangiogenic factors such as FGF, TGF- $\beta$, TNF- $\alpha$ and platelet derived growth factor (PDGF), suggesting that they may have a role in the pterygium pathogenesis. Cyclooxygenase-2 $(\mathrm{COX}-2)$ is a complex organic molecule classified in the group of enzymes, the genesis of which is influenced by different factors (growth factors, mitogens, cytokines, and tumor promoters $)^{14}$. Evidence indicates that the COX-2 - prostanoid pathway is involved in inflammation ${ }^{15,16}$. COX-2 modulates angiogenesis by increasing the production of angiogenic factors such as vascular endothelial growth factor (VEGF). There are two types of cyclooxygenase, cyclooxygenase-1 (COX1 ), present in most tissues, and COX-2, a general inflammation mediator that is involved in the metabolism of arachidonic acid, one of the modulators of the inflammatory response ${ }^{17,18}$. COX-2 is induced by the tumor-promoting factors such as ultraviolet (UV) radiation. In the skin carcinogenesis ${ }^{19-21}$ related to UV radiation, both radical oxygen species (ROS) and COX-2 play an important role ${ }^{22}$. There is an assumed direct phototoxic mechanism of UV radiation and an indirect mechanism, through the formation of ROS (so-called oxidative stress) ${ }^{2}$, which damages cells and induces the synthesis of COX-2, which further stimulates prostaglandin E2 (PGE2). Chiang et al..$^{23}$ and Fischer et al. ${ }^{24}$ assumed COX-2 to induce the synthesis of PGE2, which acts as a mitogen, and to inhibit apoptosis resulting in persistence of the so-called 'sunburn cells' that would normally degrade by apoptosis in the epidermis. This mechanism reduces the ability of cells to mask, and they become more exposed to tumorigenic factors increasing the accumulation of deoxyribonucleic acid (DNA) damage and reducing the ability of repairing damaged $\mathrm{DNA}^{2,25}$. Maxia et al. ${ }^{26}$ suggest a strong correlation of COX-2 and survivin, a protein that is an inhibitor of apoptosis (IAPs), in the group of primary pterygia developed by the assumed 'anti-apoptotic' mechanism.

\section{Patients, Materials and Methods}

This study included 111 patients treated at the Department of Ophthalmology, Osijek University Hospital Centre. The patients undergoing surgery at the Department of Ophthalmology, Osijek University Hospital Centre from 2010 to 2013 were divided into two groups. Group 1 consisted of patients having undergone $3^{\text {rd }}$ and $4^{\text {th }}$ degree primary pterygium of the eye conjunctiva surgery. Group 2 consisted of patients having undergone cataract surgery (mainly by phacoemulsification), without degenerative changes on the conjunctiva. Patients with recurrent pterygium and other conjunctival pathology, those with inflammatory eye and/or systemic inflammatory disease, and patients with any topical therapy (because of therapy side effects such as hyperemia, effects of preservatives on the surface of the eye or immunosuppression effect) were excluded from the study due to possible false positive findings of COX-2 activity. All patients provided their informed consent for participation in the study.

Data were collected through surveys preoperatively and postoperatively at regular check-ups (demographic data, exposure to external conditions, occupation, level of education, comorbidities). The surveys were applied individually, containing closed-ended questions and open-ended questions.

During the $3^{\text {rd }}$ and $4^{\text {th }}$ degree primary pterygium surgery (group 1), the removed tissue was taken, continuing the operation routinely. In group 2 , the nasal bulbar conjunctiva specimen (minimum $3 \times 3 \mathrm{~mm}$ ) was obtained immediately after finishing the cataract surgery, more precisely, at the moment when the eye is 'closed', with the aim of intraoperative risk reduction. Apart from the anesthetic, which has no impact on the results of the COX-2 analysis, no other medication was administered before taking the sample.

All specimens were fixed overnight in 10\% buffered formalin before being embedded in paraffin. Three- $\mu \mathrm{m}$ thick sections were cut and stained using hematoxylin and eosin (H\&E). For immunohistochemical staining, all sections were deparaffinized in xylene and hydrated in descending dilution of ethanol. For the antigen, specimen slides were put in a preheated buffer solution maintaining heat in a water 
Table 1. Age and sex distribution of patients in control and experimental groups

\begin{tabular}{|c|c|c|c|c|}
\hline & \multicolumn{4}{|c|}{ Parameter value } \\
\hline & Control group & Experimental group & Total & $\mathrm{p}$ \\
\hline Sex: & & & & \\
\hline male & $14(32.6)$ & $31(45.6)$ & $45(40.5)$ & $0234^{*}$ \\
\hline female & $29(67.4)$ & $37(54.4)$ & $66(59.5)$ & 0.234 \\
\hline Age (years) & $77(66-81)$ & $62(54-72.8)$ & $68(57-77)$ & $<0.001^{\dagger}$ \\
\hline Age group (years): & & & & \\
\hline$\leq 39$ & 0 & $2(2.9)$ & $2(1.8)$ & \\
\hline $40-49$ & 0 & $7(10.3)$ & $7(6.3)$ & \\
\hline $50-59$ & $4(9.3)$ & $20(29.4)$ & $24(21.6)$ & 00001 * \\
\hline $60-69$ & $9(20.9)$ & $17(25)$ & $26(23.4)$ & $<0.001$ \\
\hline $70-79$ & $16(37.2)$ & $16(25.5)$ & $32(28.8)$ & \\
\hline$\geq 80$ & $14(32.6)$ & $6(8.8)$ & $20(18)$ & \\
\hline Total & $43(38.7)$ & $68(61.3)$ & $111(100)$ & \\
\hline
\end{tabular}

*Fisher exact test; ${ }^{\dagger}$ Mann Whitney test

bath $\left(95-99^{\circ} \mathrm{C}\right)$. The specimen slides were tested with COX-2 antibody (1:100; M361701 MO A-HU, Dako, Santa Clara, California, USA). Macrophages found in mucosa of the small intestine and colon samples with proven inflammatory bowel disease were used as positive control in COX-2 immunostaining, whereas negative controls were obtained by leaving out primary antibody. The intensity of immunostaining in the surface epithelium was scored using the following grading system: 0 no immunostaining; + weak immunostaining (few cells positive focally or scattered); ++ medium immunostaining; and +++ strong immunostaining (diffuse staining throughout the tissue).

\section{Ethics}

The study protocol was approved by the institutional Ethics Committee and performed according to ethical principles of the 1975 Helsinki Declarations, as revised in 1983.

\section{Statistics}

Standard descriptive methods were used. Categorical variables were expressed by absolute and relative frequencies. Mean values of continuous variables were expressed as median and interquartile range. To explore the difference between the two independent groups, Mann-Whitney test was performed, whereas differences between categorical variables were tested by Fisher exact test. Using the logistic regression method, the impact of multiple predictors was assessed regarding the possibility of developing COX-2 antibodies in the study subjects. Data were analyzed by statistical methods of testing using SPSS 15.0 (SPSS Inc., Chicago, IL, USA). The level of statistical significance was set at $\mathrm{p}=0.05$.

\section{Results}

The study included 111 patients, $68(61.3 \%) \mathrm{pa}^{-}$ tients having undergone primary pterygium surgery (group 1) and 43 (38.7\%) patients with morphologically unchanged conjunctiva (group 2). Gender distribution was similar (M:F ratio, 45:66). The mean age of patients was 68 (interquartile range 57-77) years, but group 2 patients were significantly older (Mann Whitney test, $\mathrm{p}<0.001$ ) (Table 1 ). Most of the patients (66.7\%) lived in rural areas, which is associated with lifestyle resulting in greater long-term sun exposure. Lower educational levels were recorded in 54 (48.7\%) of all study patients, without significant betweengroup differences (22:32), which affected their lifestyle as they were working outdoors more often (agriculture). Working outdoors were forty patients (36\%- occupation related). To sunlight were exposed 87 (78.4\%) patients with no significant difference between the groups. The mean number of years of sun exposure was 
Table 2. Patient distribution according to residence, education level, occupation, sun exposure and positive vs. negative $C O X-2$ findings

\begin{tabular}{|c|c|c|c|c|}
\hline & \multicolumn{4}{|c|}{ Parameter value } \\
\hline & Group 2 & Group 1 & Total & $\mathrm{p}$ \\
\hline $\begin{array}{l}\text { Residence: } \\
\text { urban } \\
\text { rural }\end{array}$ & $\begin{array}{ll}13 & (30.2) \\
30 & (69.8)\end{array}$ & $\begin{array}{l}24(35.3) \\
44(64.7)\end{array}$ & $\begin{array}{l}37(33.3) \\
74(66.7)\end{array}$ & $0.542^{*}$ \\
\hline $\begin{array}{l}\text { Level of education: } \\
\text { illiterate } \\
\text { low qualification } \\
\text { high school } \\
\text { university degree } \\
\text { elementary school }\end{array}$ & $\begin{array}{l}1(2.3) \\
22(51.2) \\
17(39.5) \\
3(7) \\
0\end{array}$ & $\begin{array}{l}1(1.5) \\
32(47) \\
32(47) \\
1(1.5) \\
2(3)\end{array}$ & $\begin{array}{l}2(1.8) \\
54(48.7) \\
49(44.1) \\
4(3.6) \\
2(1.8)\end{array}$ & $0.656^{*}$ \\
\hline $\begin{array}{l}\text { Occupation: } \\
\text { outdoor work }^{\ddagger} \\
\text { indoor work }^{* *} \\
\text { work with chemicals, dust, high temperatures*** }\end{array}$ & $\begin{array}{l}15(34.9) \\
24(55.8) \\
4(9.3)\end{array}$ & $\begin{array}{l}25(36.8) \\
37(54.4) \\
6(8.8)\end{array}$ & $\begin{array}{l}40(36) \\
61(55) \\
10(9)\end{array}$ & $>0.950^{*}$ \\
\hline $\begin{array}{l}\text { Sun exposure: } \\
\text { yes } \\
\text { no }\end{array}$ & $\begin{array}{ll}32 & (74.4) \\
11 & (25.6)\end{array}$ & $\begin{array}{ll}55 & (80.9) \\
13 & (19.1)\end{array}$ & $\begin{array}{l}87(78.4) \\
24(21.6)\end{array}$ & $0.481^{*}$ \\
\hline Sun exposure (years) & $48(28.5-59)$ & $22(5-35)$ & $30(12-50)$ & $<0.001^{\dagger}$ \\
\hline $\begin{array}{l}\text { COX-2 antibody analysis: } \\
\text { negative } \\
\text { positive }\end{array}$ & $\begin{array}{l}16(37.2) \\
27(62.8)\end{array}$ & $\begin{array}{ll}39 & (57.4) \\
29 & (42.6)\end{array}$ & $\begin{array}{l}55(49.5) \\
56(50.5)\end{array}$ & $0.175^{\S}$ \\
\hline
\end{tabular}

*Fisher exact test; ${ }^{\dagger}$ Mann Whitney test; ${ }^{\S} \mathrm{McNemar}$ test; ${ }^{\ddagger}$ outdoor work: farmers, drivers, loggers, construction workers; ${ }^{* *}$ indoor work: maids, housewives, unemployed, pensioners, crafts related to confined spaces; ${ }^{* * *}$ large furnace stokers, bakers, workers in textile and chemical industries

significantly higher (48:22) in group 2 (Mann Whitney test, $\mathrm{p}<0.001)$. According to COX-2 analysis, positive results were found in $56(50.5 \%)$ patients, 29 (42.6\%) of which in group 1 with primary pterygium and 27 (62.8\%) in group 2 (Table 2).

Positive findings of COX-2 antibodies were significant among elderly patients, median age 73.5 (interquartile range 60-79 years; Mann Whitney test, $\mathrm{p}=0.032$ ). The mean number of years of sun exposure was 30 years. COX-2 positive findings were significantly higher in the group of patients with more years of exposure, i.e. 36 (interquartile range 20-52.5) years, than in those with negative findings (Mann Whitney test, $\mathrm{p}=0.003)$. There were no significant gender differences (Table 3, Figs. 1 and 2).

Logistic regression was used to assess the impact of several factors on the likelihood of study patients to develop positive COX-2 antibodies. The model con- tains seven variables that influence positive COX-2 findings (gender, age, sun exposure duration in years, residence (urban or rural), and most common comorbidities including arterial hypertension, diabetes mellitus, and cardiomyopathy) (Table 4).

As a model, statistically significant predictors $\left(\chi^{2}=30.15 ; \mathrm{df}=3 ; \mathrm{p}=0.003\right)$ were observed (gender, age and duration of sun exposure in years), indicating that these were capable of differentiating patients according to the clinical picture of COX-2 positive findings, thus completely explaining $15 \%$ (Cox \& Snell) to 20\% (Negelkerke) of variance in the presence of positive finding, and accurately classifying $66.7 \%$ of cases. The strongest predictor was duration of sun exposure in years (Table 5).

In group 1, duration of sun exposure could not be determined in 13 (19\%) patients. In the remaining 55 (81\%) patients, difference in the antibody COX-2 
Table 3. Mean values of gender, age and sun exposure expressed in years according to positive vs. negative COX-2 antibody analysis

\begin{tabular}{|l|l|l|l|l|}
\hline \multirow{2}{*}{} & \multicolumn{3}{|c|}{ Treatment of COX-2 antibodies } & \multirow{2}{*}{ p } \\
\cline { 2 - 5 } & Negative & Positive & Total & \\
\hline Gender: & & & & \\
male (\%) & $17(30.9)$ & $28(50)$ & $45(40.5)$ & $0.053^{*}$ \\
female (\%) & $38(69.1)$ & $28(50)$ & $66(59.5)$ & $0.032^{\dagger}$ \\
\hline Age (years) & $64(56-74)$ & $73.5(60-79)$ & $68(57-77)$ & $0.003^{\dagger}$ \\
\hline Sun exposure (years) & $21(3.9-40)$ & $36(20-52.5)$ & $30(12-50)$ & \\
\hline
\end{tabular}

*Fisher exact test; ${ }^{\dagger}$ Mann Whitney test

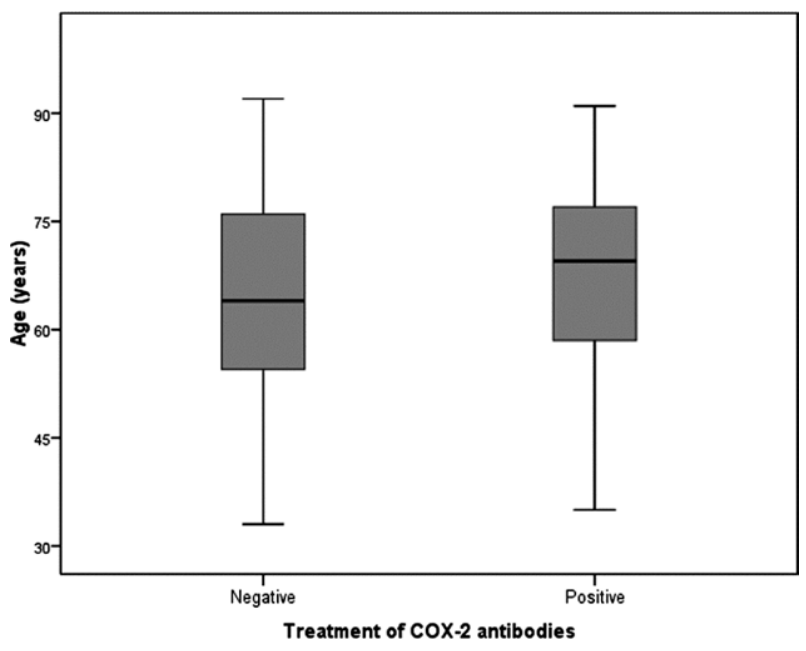

Fig. 1. COX-2 antibody distribution according to patient age (median and interquartile range).

COX-2 = cyclooxygenase 2

findings in pterygium tissue (depending on the duration of sun exposure in years) proved the increase in the duration of sun exposure to have led to poorer findings (Fisher exact test, $\mathrm{p}=0.008$ ) (Table 6).

\section{Discussion}

Analysis of our study groups showed sun exposure duration to be the strongest predictor in assessing the probability that patients would develop COX-2 antibodies $(\mathrm{p}=0.043)$. Geographical variations in the incidence of diseases such as pterygium have led to theories pointing at sun exposure as a potential etiologic factor $^{7-9}$. Epidemiologic studies indicate that chronic exposure to sunlight, and most probably UV radiation, is an important factor in pterygium development ${ }^{10}$.

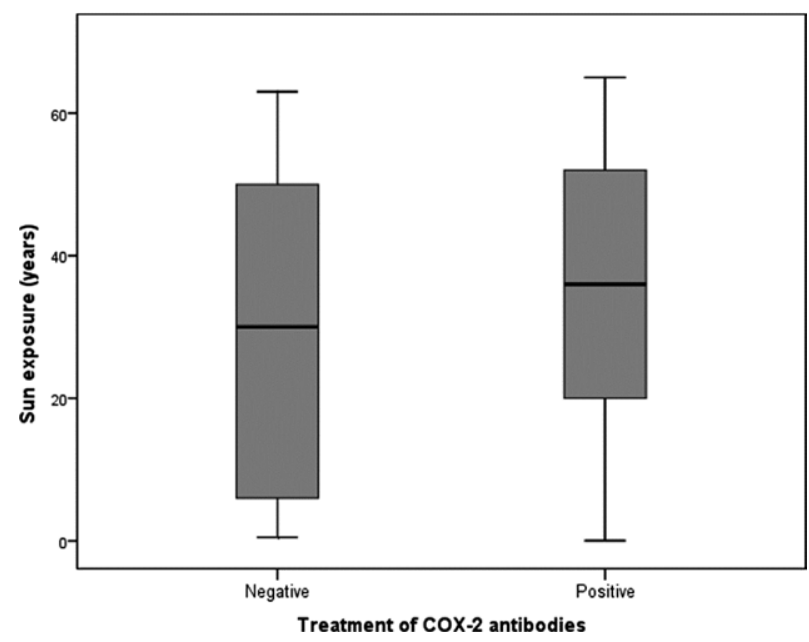

Fig. 2. COX-2 antibody distribution according to sun exposure expressed in years (median and interquartile range)

COX -2 = cyclooxygenase 2

The first international meta-analysis included 20 studies (English and Chinese) and showed the pooled prevalence of pterygium to be relatively high (10.2\%), especially in low $\left(20^{\circ}-30^{\circ}\right)$ latitude regions and elderly population ${ }^{27}$. Similarly, the prevalence of pterygium in a Tibetan population at high altitude is significantly high $^{8}$. The primary causative factors are related to ocular sun exposure, which coincides with the results of our study. Positive COX-2 was found in a significant number of patients that had been exposed to sun for a number of years ( $p=0.003)$. Group 2 consisted of a significantly older population $(p=0.032)$ with a higher mean value of sun exposure in years. Therefore, the cumulated effect of sun exposure should have yielded more positive COX-2 findings than in group 1 with a lower total number of years of sun exposure. The in- 
Table 4. Effect of particular predictors of positive findings on $\mathrm{COX}-2$ prevalence (univariate regression analysis)

\begin{tabular}{|l|l|l|l|l|l|l|}
\hline & $\beta$ & $\begin{array}{l}\text { Standard } \\
\text { error }\end{array}$ & Wald & $p$ & $\begin{array}{l}\text { Odds ratio } \\
\text { (Exp } \beta)\end{array}$ & $\begin{array}{l}\text { 95\% CI } \\
\text { for Exp } \beta\end{array}$ \\
\hline Gender & -0.804 & 0.396 & 4.132 & 0.042 & 0.447 & $0.206-0.972$ \\
Age & 0.033 & 0.016 & 4.304 & 0.038 & 1.034 & $1.002-1.067$ \\
Duration of sun exposure (years) & 0.034 & 0.012 & 8.505 & 0.004 & 1.034 & $1.011-1.058$ \\
Residence (urban/rural) & 0.274 & 0.406 & 0.455 & 0.500 & 1.315 & $0.594-2.912$ \\
Arterial hypertension & 0.471 & 0.382 & 1.518 & 0.218 & 1.602 & $0.757-3.389$ \\
Diabetes mellitus & -0.442 & 0.534 & 0.408 & 0.408 & 0.643 & $0.226-1.832$ \\
Cardiomyopathy & 0.955 & 0.859 & 1.234 & 0.267 & 2.598 & $0.482-14.0$ \\
\hline
\end{tabular}

COX-2 = cyclooxygenase $2 ; 95 \% \mathrm{CI}=95 \%$ confidence interval

Table 5. Predicting the likelihood of patients with positive antibody $C O X-2$ to develop clinical symptoms (multivariate regression analysis)

\begin{tabular}{|l|l|l|l|l|l|l|}
\hline & $\beta$ & $\begin{array}{l}\text { Standard } \\
\text { error }\end{array}$ & Wald & $p$ & $\begin{array}{l}\text { Odds ratio } \\
(\operatorname{Exp} \beta)\end{array}$ & $\begin{array}{l}95 \% \text { CI for } \\
\text { Exp } \beta\end{array}$ \\
\hline Gender & 0.830 & 0.474 & 3.069 & 0.080 & 2.294 & $0.906-5.807$ \\
Age & 0.026 & 0.021 & 1.517 & 0.218 & 1.026 & $0.985-1.068$ \\
Sun exposure (years) & 0.026 & 0.013 & 4.097 & 0.043 & 1.027 & $1.001-1.053$ \\
Constant & -2.760 & 1.324 & 4.345 & 0.037 & 0.063 & \\
\hline
\end{tabular}

COX-2 = cyclooxygenase $2 ; 95 \% \mathrm{CI}=95 \%$ confidence interval

Table 6. Sun exposure duration in relation to positive COX-2 in pterygium

\begin{tabular}{|l|l|l|l|l|l|l|}
\hline \multirow{2}{*}{$\begin{array}{l}\text { Sun exposure } \\
\text { (years })\end{array}$} & \multicolumn{5}{|c|}{ Number (\%) of respondents } & \multirow{2}{*}{$\mathrm{p}^{*}$} \\
\cline { 2 - 6 } & Negative & $+^{\dagger}$ & $+^{\S}$ & $+^{\S}++^{\ddagger}$ & Total & \\
\cline { 2 - 6 }$\leq 10$ & $16(48.5)$ & $1 / 10$ & $1 / 8$ & 0 & $18(32.7)$ & \\
$11-20$ & $3(9.1)$ & $3 / 10$ & $3 / 8$ & 0 & $9(16.4)$ & \\
$21-30$ & $6(18.2)$ & $1 / 10$ & $1 / 8$ & $2 / 4$ & $10(18.2)$ & \multirow{2}{*}{0.008} \\
$31-40$ & $5(15.2)$ & 0 & $2 / 8$ & $1 / 4$ & $8(14.5)$ & \\
$41-50$ & $1(3)$ & $2 / 10$ & $1 / 8$ & $1 / 4$ & $5(9.1)$ & \\
$\geq 51$ & $2(6)$ & $3 / 10$ & 0 & 0 & $5(9.1)$ & \\
\hline Total & $33(100)$ & $10 / 10$ & $8 / 8$ & $4 / 4$ & $55(100)$ & \\
\hline
\end{tabular}

COX-2 = cyclooxygenase 2 ; ${ }^{*}$ Fisher exact test; ${ }^{\dagger}$ weak immunostaining (few cells positive focally or scattered); ${ }^{\S}$ medium intensity of immunostaining; ${ }^{\star}$ strong immunostaining (diffuse staining throughout the tissue)

creasing trend of positive COX-2 findings in older patients may be explained by the cumulative effect of sun exposure. In the international meta-analysis, there was a significant trend of greater pterygium prevalence in older ages ( $11 \%$ vs. $15.6 \%$ vs. $20.1 \%$ in $40-49$ vs. 50-59 vs. 60-69 age group, respectively), but the trends were generally similar in 60-69 and $>70$ age groups $(20.1 \%$ vs. $20.2 \%$, respectively) ${ }^{1}$. COX-2 is the main UV-responsive COX isoform in human skin and is involved in UV-induced skin inflammation and apoptosis (similar to the pathogenesis of pterygium $)^{2,25}$. Diclofenac, a topical nonsteroidal anti-inflammatory drug (NSAID), acts as a nonspecific COX inhibitor and is an effective treatment for actinic keratosis ${ }^{24}$. Oral and topical 
COX-2 inhibitors exert chemopreventive activity against UV light-induced skin cancer in animal models. The mechanism of action of COX inhibitors in skin tumorigenesis is complex and not completely understood. This poses new challenges for primary preventive measures within protection against sun exposure and encourages epidemiologically necessary actions to educate the population at large. Thus, the question of justifying secondary prevention in terms of long-term NSAID therapy as COX-2 inhibitors in individuals with the above-mentioned factors with a dominant effect on COX-2 analysis (number of years of sun exposure) should be brought up ${ }^{12,28}$. Park et al. ${ }^{29}$ believe that the expression of COX-2 and VEGF in macrophages also has an important role in the pathogenesis of pterygium. This indicates a possibility of combined therapy (e.g., NSAID and anti-VEGF). Chiang et al. ${ }^{23}$ investigated the expression of COX-2 in pterygium and $83.3 \%$ of specimens stained positive for COX-2 in the pterygium group. In our study, a similar positive result of COX-2 activity in both group 2 and group 1 with primary pterygium excluded inflammation as the only cause of pterygium. Literature search also suggests its multifactorial origin ${ }^{11,12}$.

\section{Conclusions}

As our group 2 included significantly older patients, they had more positive findings of COX-2 antibody expression $(\mathrm{p}=0.032)$. The patients having a history of longer sun exposure (expressed in years) were more often positive for COX-2 ( $p=0.003)$. The duration of sun exposure influenced the severity of findings in pterygium tissue, which positively correlated with the intensity of COX-2 activity in pterygium tissue $(p=0.008)$. Considering gender, age and duration of sun exposure as predictors of how each of them affected the findings, duration of sun exposure was demonstrated to be the strongest predictor.

\section{Acknowledgments}

The authors would like to thank all patients having participated in the study, as well as to all staff members of the Department of Clinical Pathology. The authors also greatly appreciate the help received from Magdalena Perić, PhD.

\section{References}

1. Piras F, Moore PS, Ugalde J, Perra MT, Scarpa A, Sirigu P. Detection of human papillomavirus DNA in pterygia from different geographical regions. Br J.Ophthalmol. 2003;87(7): 864-6, http:dx.doi.org/ 10.1136/bjo.87.7.864

2. Tsai YY, Cheng YW, Lee H, Tsai FJ, Tseng SH, Lin CL, et al. Oxidative DNA damage in pterygium. Mol Vis. 2005;11:71-5.

3. Clear AS, Chirambo MC, Hutt MS. Solar keratosis, pterygium and squamous cell carcinoma of the conjunctiva in Malawi. Br J Ophthalmol. 1979;63(2):102-9 http:dx.doi.org/ 10.1136/ bjo.63.2.102

4. Threlfall TJ, English DR. Sun exposure and pterygium of the eye: a dose-response curve. Am J Ophthalmol. 1999;128(3): 280-7, http:dx.doi.org/ 10.1016/s0002-9394(99)00161-0

5. Sekelj S, Dekaris I, Kondža-Krstonijević E, Gabrić N, Predović J, Mitrović S. Ultraviolet light and pterygium. Coll Antropol. 2007;31(1):45-7.

6. Vojniković B, Njirić S, Zamolo G, Toth I, Apanjol J, Coklo M. Histopathology of the pterygium in population on Croatian Island Rab. Coll Antropol. 2007;31(1):39-41.

7. Lü P, Chen XM. Prevalance and risk factors of pterygium. Int J Ophthalmol. 2009;2(1):82-5, http:dx.doi.org/ 10.1136/bjo.63. 2.102

8. Lu P, Chen X, Kang Y, Ke L, Wei X, Zhang W. Pterygium in Tibetans: a population-based study in China. Clin Exp Ophthalmol. 2007;35(9):828-33, http:dx.doi.org/ 10.1111/j. 1442-9071.2007.01630.x

9. Pelit A, Bal N, Akova YA, Demirhan B. p53 expression in pterygium in two climatic regions in Turkey. Indian J Ophthalmol. 2009;57(3):203-6, http:dx.doi.org/10.4103/0301-4738.49394

10. Fotouhi A, Hashemi H, Khabazkhoob M, Mohammad K. Prevalence and risk factors of pterygium and pinguecula: the Tehran Eye Study. Eye (Lond). 2009;23(5):1125-9. doi: 10.1038/eye.2008.200, http:dx.doi.org/ 10.1038/eye.2008.200

11. Chui J, Di Girolamo N, Wakefield D, Coroneo MT. The pathogenesis of pterygium: current concepts and their therapeutic implications. Ocul Surf. 2008;6(1):24-43.

12. Todani A, Melki SA. Pterygium: current concepts in pathogenesis and treatment. Int Ophthalmol Clin. 2009;49(1): 21-30, http:dx.doi.org/ 10.1097/IIO.0b013e3181924f62

13. Kria L, Ohira A, Amemiya T. Immunohistochemical localization of basic fibroblast growth factor, platelet derived growth factor, transforming growth factor-beta and tumor necrosis factor-alpha in the pterygium. Acta Histochem. 1996;98(2): 195-201.

14. Kuwano T, Nakao S, Yamamoto H, Tsuneyoshi M, Yamamoto T, Kuwano M, et al. Cyclooxygenase 2 is a key enzyme for inflammatory cytokine-induced angiogenesis. FASEB J. 2004;18 (2):300-10, http:dx.doi.org/ 10.1096/fj.03-0473com

15. Williams CS, Mann M, DuBois RN. The role of cyclooxygenases in inflammation, cancer, and development. Oncogene. 1999;18(55):7908-16, http:dx.doi.org/ 10.1038/sj.onc.1203286 
16. Van der Zee E, Everts V, Beertsen W. Cytokines modulate routes of collagen breakdown. Review with special emphasis on mechanisms of collagen degradation in the periodontium and the burst hypothesis of periodontal disease progression. J Clin Peridontol. 1997;24(5):297-305.

17. Karahan N, Baspinar S, Ciris M, Baydar CL, Kapucuoglu N. Cyclooxygenase-2 expression in primary and recurrent pterygium. Indian J Ophthalmol. 2008;56(4):279-83, http:dx.doi. org/ 10.4103/0301-4738.39663

18. Isoherranen K, Punnonen K, Jansen C, Uotila P. Ultraviolet irradiation induces cyclooxygenase-2 expression in keratinocytes. Br J Dermatol. 1999;140(6):1017-22.

19. Vučić M, Talan-Hranilović J, Vucelić V, Rožanković S, Iveković R. Skin tumors of the periorbital region and eyelids in the 1998-2002 period. Acta Clin Croat. 2003;42(2):161-4.

20. Nola I, Kostović K, Lugović L, Meštrović-Štefekov J, Sjerobabski-Masnec I. Ultraviolet radiation and the skin immune response. Acta Clin Croat. 2003;42(2):119-23.

21. Rundhaug JE, Mikulec C, Pavone A, Fischer SM. A role for cyclooxygenase-2 in ultraviolet light-induced skin carcinogenesis. Mol Carcinog. 2007;46(8):692-8, http:dx.doi.org/ 10.1002/mc.20329

22. Fischer SM. Is cyclooxygenase-2 important in skin carcinogenesis? J Environ Pathol Toxicol Oncol. 2002;21(2):183-91.

23. Chiang CC, Cheng YW, Lin CL, Lee H, Tsai FJ, Tseng SH, et al. Cyclooxygenase-2 expression in pterygium. Mol Vis. 2007;13:635-8.
24. Fischer SM, Lo HH, Gordon GB, Seibert K, Kelloff G, Lubet $\mathrm{RA}$, et al. Chemopreventive activity of celecoxib, a specific cyclooxygenase- 2 inhibitor, and indomethacin against ultraviolet light-induced skin carcinogenesis. Mol Carcinog. 2005;25 (4):231-40.

25. Tsujii M, DuBois RN. Alterations in cellular adhesion and apoptosis in epithelial cells overexpressing prostaglandin endoperoxide synthase 2. Cell. 1995;83(3):493-501, http:dx.doi. org/ 10.1016/0092-8674(95)90127-2

26. Maxia C, Perra MT, Demurtas P, Minerba L, Murtas D, Piras $\mathrm{F}$, et al. Relationship between the expression of cyclooxygenase-2 and survivin in primary pterygium. Mol Vis. 2009;15: 458-63.

27. Liu L, Wu J, Geng J, Yuan Z, Huang D. Geographical prevalence and risk factors for pterygium: a systematic review and meta-analysis. BMJ Open. 2013;3:e003787, http:dx.doi.org/ 10.1136/bmjopen-2013-003787

28. Rainsford KD. Anti-inflammatory drugs in the $21^{\text {st }}$ century. Subcell Biochem. 2007;42:3-27, http:dx.doi.org/ 10.1007/14020-5688-5_1

29. Park CY, Choi JS, Lee SJ, Hwang SW, Kim EJ, Chuck RS. Cyclooxygenase-2-expressing macrophages in human pterygium co-express vascular endothelial growth factor. Mol Vis. 2011;17:3468-80.

Sažetak

\section{UTJECAJ TRAJANJA SUNČEVE IZLOŽENOSTI NA AKTIVNOST CIKLOOKSIGENAZE 2 U TKIVIMA SPOJNICE}

\section{P. Reisz Majić, B. Cerovski, P. Majić, I. Krković, J. Baraći I. Bradvica Štenc}

Pterigij je multifaktorijalna proliferativna promjena bulbarne spojnice. Svrha rada bila je ustanoviti utjecaj duljine trajanja solarne ekspozicije (u godinama) na incidenciju pozitivnih nalaza aktivnosti ciklooksigenaze 2 (COX-2) u dvjema skupinama tkiva spojnica. Prvu skupinu činilo je 68 operiranih bolesnika s primarnim pterigijem metodom autotransplantacije spojnice. Drugu skupinu činile su morfološki nepromijenjene spojnice 43 bolesnika operiranih zbog katarakte. Ukupno 111 uzoraka spojnice je imunohistokemijski analizirano pomoću monoklonskih antitijela COX-2 (1:100; M361701 MO A-HU, Dako). Analiza aktivnosti COX-2 spojnica pokazala je u prvoj skupini 29 (42,6\%), a u drugoj skupini 27 (62,8\%) pozitivnih nalaza. Druga skupina bila je statistički značajno starija i sa značajno većom duljinom solarne ekspozicije. Statističkom analizom dokazala se duljina solarne ekspozicije kao najznačajniji čimbenik za pozitivnost nalaza COX-2.

Ključne riječi: Konjunktiva; Ciklooksigenaza 2; Pterigij; Sunčeva svjetlost-štetno djelovanje 